\title{
The geochemistry of Diavik kimberlites, Lac de Gras, NWT., Canada
}

\author{
S. Zurevinski ${ }^{1}$, L. Heaman ${ }^{1}$, and D. Eichenberg ${ }^{2}$ \\ ${ }^{1}$ Department of Earth and Atmospheric Sciences, University of Alberta, Edmonton, Alberta, Canada \\ ${ }^{2}$ Diavik Diamond Mines Inc., Yellowknife, NWT, Canada.
}

The Diavik diamond mine is located on a 20 -square kilometre island in Lac de Gras, approximately 300 kilometres northeast of Yellowknife. Diamonds are currently mined from three kimberlites; A154 South, A154 North and A418. Sixty-eight kimberlites are currently recognized on the Diavik property and several of these have been dated, yielding emplacement ages between 54.7 and $56 \mathrm{Ma}$ (Graham et al. 1999; Creaser 2004). Fresh macrocrystal phlogopite extracted from two samples in this study, Anik and A841, yield $\mathrm{Rb}-\mathrm{Sr}$ ages of $55.8 \mathrm{Ma}$ and $56.7 \mathrm{Ma}$, respectively. These emplacement ages are in excellent agreement with previous ages from the Diavik property. Further attempts at emplacement ages were unsuccessful due to the absence of perovskite and extreme alteration and replacement of macrocrystal phlogopite.

Over 125 kimberlite samples were collected from drill core and pit sampling for petrography and classification, representing a total of 38 known kimberlites on the property. A suite of 42 samples were carefully chosen for whole rock geochemistry in order to better constrain primary kimberlite magma compositions, and evaluate intra-field geochemical variations.

A suite of 95 thin sections were examined and classified on the basis of lithology and texture. Identification of all primary minerals present in the kimberlites was difficult due to the alteration and high abundance of lithic material. The Diavik kimberlites have been classified as follows: resedimented volcaniclastic $>$ volcaniclastic $>$ olivine-bearing volcaniclastic $>$ mud-bearing volcaniclastic $>$ macrocrystic oxide-bearing hypabyssal kimberlite > sparsely-macrocrystic calcite oxide hypabyssal kimberlite $>$ tuffisitic kimberlite breccia.

Microprobe analyses of olivine show a significant overlap in mol. \% Fo. Macrocrystal olivine Fo content ranges from 89-93, phenocrystal olivine ranges 90-92, while microphenocrystal olivine ranges from 88-91. This overlap is probably due to the presence of fragmental olivine identified from petrography. An overall slightly higher Fo content is shown for the olivine macrocrysts relative to the phenocrysts and microphenocrysts. The macrocrysts are considered to be xenocrystic in origin, in agreement with petrographic evidence.

Spinel compositions of magmatic (HK) samples plot along magmatic trend \#1 (after Mitchell and Clarke, 1976) (Figure 1). This trend shows increasing Ti, decreasing $\mathrm{Cr}$ and constant $\mathrm{Fe} /(\mathrm{Fe}+\mathrm{Mg})$. The samples from the A154 and T31 kimberlites represent the analyses of kimberlitic spinel from volcaniclastic kimberlite and plot exclusively in the TiMAC/TMC fields.

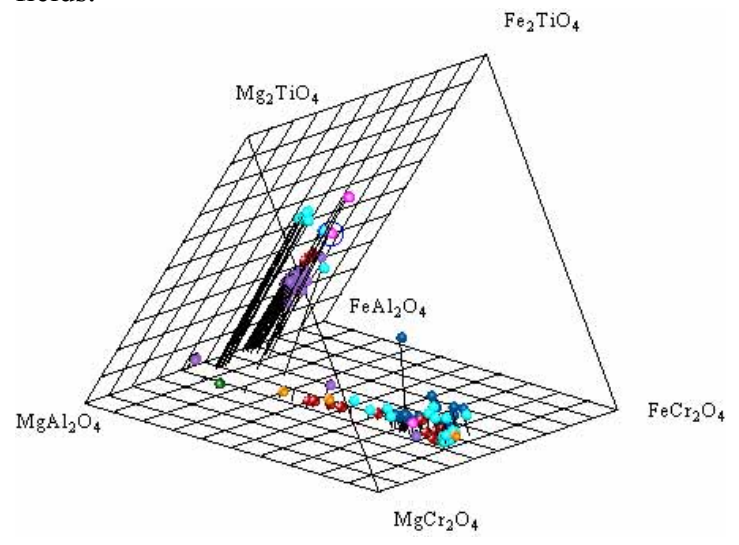

Figure 1. A reduced spinel prism with compositions of Diavik spinels representing the magnesian ulvöspinel trend (after Mitchell and Clarke, 1976).

Geochemical contamination indices (C.I. $=\left(\mathrm{SiO}_{2}+\right.$ $\left.\left.\mathrm{Al}_{2} \mathrm{O}_{3}+\mathrm{Na}_{2} \mathrm{O}\right) /\left(\mathrm{MgO}+2 \mathrm{~K}_{2} \mathrm{O}\right)\right)$ range from 0.91-2.7, reflecting both alteration and the abundance of lithic material in the kimberlites. The least contaminated samples (i.e. C.I. <1.5) were used as a proxy for "fresh" kimberlite and only the geochemical compositions of these samples are considered below. Trace element abundances ( $\mathrm{Sc}, \mathrm{V}, \mathrm{Cr}, \mathrm{Co}, \mathrm{Ni}, \mathrm{Cu}$, and $\mathrm{Zn}$ ) exhibit normal averages for kimberlitic rocks, and are hosted in the Diavik kimberlites by spinel, diopside, olivine, and sulphides. Diavik kimberlites have low and restricted ranges of $U$ and $T h$, as well as low $\mathrm{Th} / \mathrm{U}$ ratios (1-10). $\mathrm{Zr} / \mathrm{Hf}$ ratios (35-46) compare well to other kimberlite localities worldwide (e.g. South African kimberlites = 35-50; (Mitchell, 1986)), and is independent of age of magmatism. The low abundance of $\mathrm{Zr}$ and $\mathrm{Hf}$ in the kimberlites at Diavik reflect the near absence of perovskite and the low abundance of garnet in the non-economic samples. The 
consistent $\mathrm{Zr} / \mathrm{Hf}$ ratios indicate the source(s) of the Diavik kimberlites to be consistent with kimberlites worldwide, however, the lower abundance of $\mathrm{Zr}$ and $\mathrm{Hf}$ may reflect a different degree of partial melting from this similar source.

Other geochemical features of Diavik kimberlites include; 1) LREE enrichment $(\mathrm{La} / \mathrm{Sm}$ range $=12-31)$, 2) large intra-field range in REE content, and 3) similar patterns to worldwide kimberlites (Figure 2).

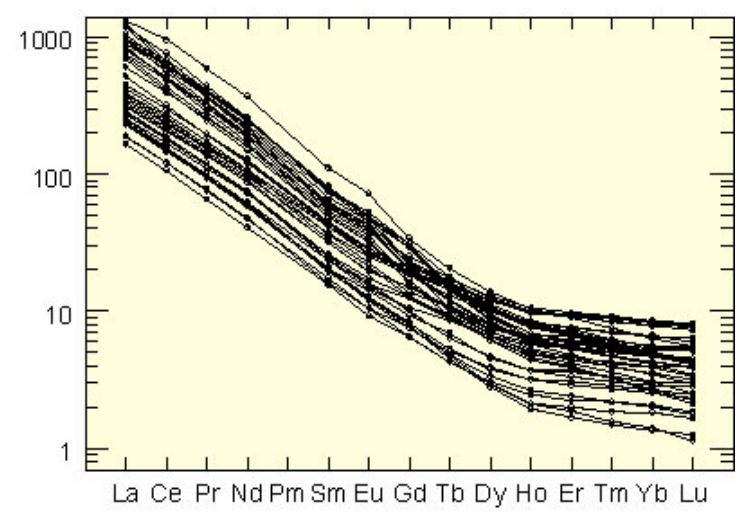

Figure 2. REE patterns of Diavik kimberlites.

\section{References}

Creaser, R. A., Grütter, H., Carlson, J. \& Crawford, B. (2004). Macrocrystal phlogopite Rb-Sr dates for the Ekati property kimberlites, Slave Province, Canada: evidence for multiple intrusive episodes in the Paleocene and Eocene. Lithos 76, 399-414.

Graham, I., Burgess, J. L., Bryan, D., Ravenscroft, P.J., Thomas, E., Doyle, B.J., Hopkins, R., and K.A. Armstrong. 1999. Exploration history and geology of the Diavik kimberlites, Lac de Gras, Northwest Territories, Canada. Seventh International Kimberlite Conference, vol.1, pp. 262279.

Mitchell, R.H. (1986). Kimberlites. Plenum Press, New York.

Mitchell, R.H. \& Clarke, D.B. (1976). Oxide and sulphide mineralogy of the Peuyuk kimberlite, Somerset Island, N.W.T., Canada. Contributions to Mineralogy and Petrology $\mathbf{5 6}, 157-172$ 